\title{
Causality of Fiscal Policies and Per Capita Income Development: Evidence from the Nigerian Economy
}

\author{
Suoye Igoni ${ }^{{ }^{\triangleright}}$ \\ Itotenaan Henry Ogiri ${ }^{2}$
}

'Department of Banking And Finance University of Nigeria, Nsukka, Nigeria.

Email:suoye.igoni.pg.00s69@unn.edu.ng

${ }^{2}$ Co-Ordinator, Ph.D. International Collaboration Postgraduate Business School Gregory University, Uturu, Nigeria.

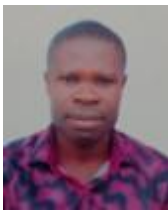

Corresponding Author)

\section{Abstract}

The growing dependency among the working population of Nigerians and basic infrastructures decay despite the upward budgetary allocation initiated to this study. The purpose of this study is to examine the response of Nigerians welfare to budgetary increase. The study, therefore, measures the causality of selected Fiscal policies- Government Capital Expenditure (GCX) and Government Recurrent Expenditure (GRX), and its prevailing development on per capita income (PCI) development in the Nigerian economy. The study employed data sourced from the Central Bank of Nigeria over the period 1981-2016. The Augmented Dickey-Fuller (ADF) and Granger Causality tests were applied. The results of the ADF test shown are stationary at first levels differenced. The results of the Granger Causality test indicate government recurrent expenditure (GRX) significantly promotes per capita income (PCI). The study concludes that GRX constitutes a significant variables policy that predicts per capita income development. The study recommends that the Federal Ministry of finance provide employment and business credits assistance to reduce the level of the unemployment rate. Recurrent expenditures like wages and salaries as well as transfer payments should be prompt to help invigorate small businesses in Nigeria.

Keywords: Fiscal Policy, Granger Causality, Per Capita Income, GCX, GRX \& Nigeria.

JEL Classification: Fiscal Policy is macroeconomic indicator, Granger Causality is test model, Per Capita Income is a measurement of development, GCX is project expenditure provided in government budget, GRX is recurrent expenditure salaries and administrative expenses in the budget, Nigeria is the country of study.

Citation | Suoye Igoni; Itotenaan Henry Ogiri (2020). Causality of Fiscal Policies and Per Capita Income Development: Evidence from the Nigerian Economy. Economy, 7(1): 19-24.

History:

Received: 7 February 2020

Revised: 9 March 2020

Accepted: 13 April 2020

Published: 1 May 2020

Licensed: This work is licensed under a Creative Commons Attribution 3.0 License $(\mathrm{cc})$ (Er

Publisher: Asian Online Journal Publishing Group
Acknowledgement: Both authors contributed to the conception and design of the study.

Funding: This study received no specific financial support

Competing Interests: The authors declare that they have no conflict of interests.

Transparency: The authors confirm that the manuscript is an honest, Transparency: The authors confirm that the manuscript is an honest,
accurate, and transparent account of the study was reported; that no vital features of the study have been omitted; and that any discrepancies from the study as planned have been explained.

Ethical: This study follows all ethical practices during writing.

\section{Contents}

1. Introduction 20

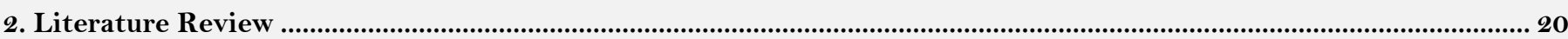

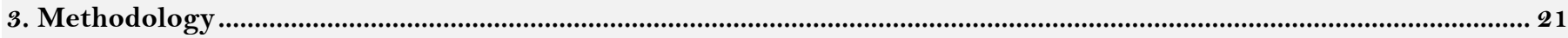

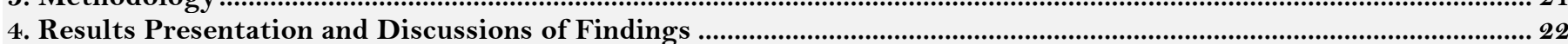

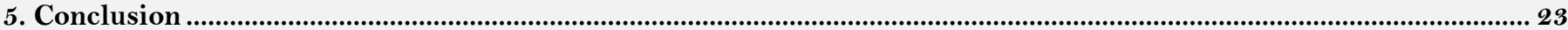

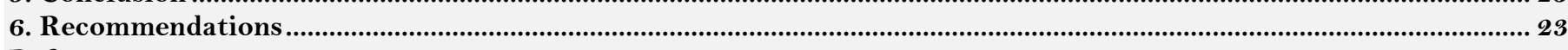

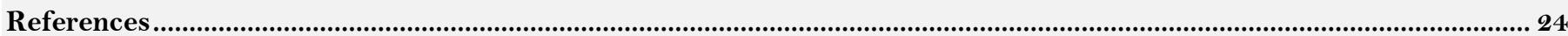




\section{Contribution of this paper to the literature}

This study contributes to existing literature by examining the response of Nigerians welfare to budgetary increase.

\section{Introduction}

The challenge of the rapid growth of the unemployment rate, the unstable balance of payment equilibrium and the poor living standard persist in Nigeria. Despite the lofty expectations from the fiscal policies, authorities appear no significant impact in the Nigerian economy development. Nigerian government through the fiscal policy in 2018 presented by His Excellency, President Muhammadu Buhari as reported by Steven (2017) in the Highlights of 2018 FGN Budget of Consolidation Presentation Speech, projected revenue of 11.983 trillion and expected capital and recurrent expenditures of $\$ 2.428$ trillion and $\$ 3.494$ trillion respectively. Others were debt services \$2.014 trillion, statutory transfer of about $\$ 456$ billion and sinking fund $\$ 220$ billion. The problem of per capita income in comparison with developed countries despite huge budgetary allocation is still nothing to write home about. The Federal government of Nigeria in an attempt to control these national instabilities established ministries and departments. This serves as a regulatory agency with the responsibility to collaborate with the ministry of finance to maintain stable economic growth rate through the application of fiscal policies and improve per capita income of Nigerians. Fiscal policy is a vital instrument used by the government to influence and maintain a stable desired economic growth and development. Economists have been well aware of its two-side effects in promoting economic growth. Previous studies have found no consensus on the impact of fiscal policy on economic growth rate. The effects of fiscal policy although are confirmed as positive in most of the studies. However, the degree of such impact depends on the absorbable capacity of the host country, which consists of the class of human capital, infrastructure, financial and institutional development as well as trade policies.

The attempt for considering the relationship between fiscal policy and regulations in determining the economic growth in per capita income has remained important. Some economists believe that while government consumption hurts the economic growth of any economy. That is if those government investments can be considered one of its paramount beneficial factors. Tsoukis and Miller (2003) in their studies, include the determinant factors of economic growth as tax rate, public capital, and recurrent expenditures. The inclusions of taxes were based on the notion that the size of government is limited by the need to finance such spending. Most studies have utilized aggregate measures of government size in the form of growth in government consumption as a ratio to GDP. The study by Seymour and Oral (1997) addresses the issue of the impact of the composition of fiscal policy on growth through the framework developed by Devarajan, Swaroop, and Zou (1996). Their analysis evaluates which categories of fiscal policy are productive, and which categories can be pruned during fiscal adjustment.

According to Ogbole, Amadi, and Essi (2011) only 14 percent contribute to GDP during deregulation than regulation periods in fiscal policies. Most Nigerians have doubts about full compliance with the budget. And it seems there are pockets of misappropriation. Abata, Kehinde, and Bolarinwa (2012) were a concern for budgetary malpractices in the government sector and such employed theoretical exploration. These efforts have not yet healed the injuries of Nigerians welfare.

This problem of low per capita income has generated questions on whether its causes are related to overpopulation, wrong statistical information, and low level of production by the citizens or improper policies management on the side of the government. There is a serious concern to the negative turning point of the Nigerian economy in these recent times. The most recent is the recession between 2016 and 2017. Several researchers have variedly evaluated this problem but conflict in results prevails.

In the light of the above, there is an urgent need to evaluate the extent to which these selected fiscal policiesgovernment capital expenditures, and government recurrent expenditures and how these variables promote growth rate in per capita income or support each other using recent data within Nigeria. The above key issues constitute the core problem and motivation for this study. This study hypothesized that fiscal policies did not significantly direct per capita income in the Nigerian economy. The study sought to answer the question: To what extent does fiscal policy significantly granger causes per capita income in the Nigerian economy? To examine this question, the study intends to evaluate the Causality of Fiscal Policies and Per Capita Income Development in the Nigerian economy.

\section{Literature Review}

Scholars of the fiscal school of thought have been in a battle on its efficacy of a better policy for regulations. The combination of both monetary and fiscal policies for refocusing economic growth and combating distress makes it important. At the time of great depression, a good number of economists confirmed that fiscal policy vehicles played complementary roles with monetary.

Although, according to public interest theory analyzed by Hertog (1999). The public interest theory of regulation emphasized that government policies may be efficient when market failures are present and private law offers no efficient solution. This theory assumed that market failures exist and that regulation is the most effective means of combating unbalance situations. This theory further explains that regulation can be accounted for as an efficient solution to an unbalance environment due to market failures.

So, regulation is imperative when economic activities are unbalanced. An unbalance situation may result in structural unemployment which could lead to low per capita income. And to achieve a desirable per capita income, there is every need for proper regulations gears towards economic stabilization. Stabilization of the trade cycle can be desirable to prevent the decline of production and employment such that different social groups are unequally affected by the economic rise and fall. The theory of unbalance as it is stated, that the trade cycle policies are put together with instruments of budgetary and monetary policies, Snowdon, Vane, and Wynarczyk (1994).

Fiscal policy remains a vital instrument used by the government to influence and maintain a stable desired economic growth and development. Economists have been well aware of its two-side effects in promoting economic growth. Previous studies have found no consensus on the impact of fiscal policy on economic growth rate. The 
effects of fiscal policy although are confirmed as positive in most of the studies. However, the degree of such impact depends on the absorbable capacity of the host country, which consists of the class of human capital, infrastructure, financial and institutional development as well as trade policies.

The attempt for considering the relationship between fiscal policy and regulations in determining the economic growth in per capita income has remained important. Some economists believe that while government consumption hurts the economic growth of any economy. That is if those government investments can be considered one of its paramount beneficial factors. Tsoukis and Miller (2003) included the determinant factors of economic growth as tax rate, public capital, and recurrent expenditures. The inclusions of taxes were based on the notion that the size of government is limited by the need to finance such spending. Most studies have utilized aggregate measures of government size in the form of growth in government consumption as a ratio to GDP.

\subsection{Empirical Review}

The debate on fiscal policy on Nigerian per capita income development has generated a number and different opinions. The work conducted by Michael and Olufemi (2017) employ OLS and St. Louis's evaluation to examine the relative impact of fiscal policy using government expenditure has a negative and insignificant influence on GDP. Again, Anyalechi, Onwumere, and Boloupremo (2017) show no evidence of a significant impact of fiscal policies on the Nigerian economy. Conversely, Monogbe, Achugbu, and Davies (2016) identify that fiscal policies regulations promote the Nigerian economy process, but failed to establish the aspect of per capita income.

However, Victor (2017) uses a set of theoretical approaches to determine the extent of fiscal policy regulations on the inflation rate and GDP in Nigeria. The results show a weak level of regulation. There was no coordination during periods of high inflation and GDP. Furthermore, Morakinyo, David, and Alao (2018) applied the Ordinary Least Square (OLS) and Vector Error Correction model to find out the impact of fiscal policy instruments on Nigerian economic growth. The results revealed a negative relationship between recurrent expenditure and public domestic debt, while capital expenditures and external debt showed a positive long-run relationship. The study however opined for effective debt management formulations.

In light of the above, it can be observed that fiscal policy is an accepted avenue to impact the Nigerian economy positively. Its core objective of adding value to per capita income has not been achieved. This subject matter has manifested to concerned academic debate. The few studies in Nigeria reviewed here indicates a mixture of results and conclusions. These results can largely be said to have followed the same pattern. Hence, the above studies were only interested in short-run relationships and lags events, and this was more reasons for employing OLS, VAR, Co-integration, and Auto-Regressive Distributed Lag (ARDL). Largely, these studies omit to examine the extent to which fiscal policy development promotes growth rate in per capita income.

\section{Methodology}

The study adopted the ex-post facto research design. The study employed secondary data to measure the causal impact of fiscal policies on per capita income in the Nigerian economy. The fiscal policies included government capital and recurrent expenditure.

The data is sourced from the Central Bank of Nigeria (CBN) Statistical Bulletin (various issues) over the period 1981 to 2016. They consisted of Per capita income as a proxy for GDP growth rate and also, the selected fiscal policy variables which include government capital expenditure rate, and government recurrent expenditure rate. Given the objective of evaluating the interrelationship between those set of variables, the functional model is therefore stated as follows:

\section{$P C I=f($ Fiscal policies}

Taking PCI to be Per Capita Income indicator and Fiscal policies predictors such as government capital expenditure rate, and government recurrent expenditure rate, the study empirically estimate functional relationships as follows:

Where

$$
P C I=f((\mathrm{GRXt}, \mathrm{GCXt}))
$$

PCI = Per Capita Income over time.

GRX = Government Recurrent Expenditure over time, $\mathrm{t}$.

GCX $=$ Government Capital Expenditure over time, $\mathrm{t}$.

From the theoretical standpoint, this study is designed to prove the reality or otherwise of the social welfare policy using variables from the Nigerian economy.

Generally, the regression form, following (Neter, Wasseraman, \& Kutner, 1989), Equation 1 and 2 can be rewritten in econometric form, thus:

$$
P C I_{t}=\gamma_{0}+\gamma_{1} G R X+\gamma_{2} G C X_{t}+\varepsilon_{t}
$$

This equation try explained that, to achieve higher per capita income it's the proper combination of government capital and recurrent expenditures.

Where all the variables are as stated above and $\gamma_{0}=$ the constant (the value of the dependent variable when all the regressors are at zero); $\gamma_{1}-\gamma_{2}$ are coefficient of the independent variables and $\varepsilon_{t}$ is the noise or error term.

The model's variables of this study consisted of monetary policy as a broad dependent variable that is being influenced in the per capita income, which serves as independent variables. The dependent variables of this study consist of the sustainable economic development of the Central Bank of Nigeria and serve as the proxy for per capita income. The independent variables of this study consist of Government Recurrent Expenditure and Government Capital Expenditure of the Central Bank of Nigeria. They serve as the explanatory variables for the fiscal policies.

The estimation procedure for this work followed Granger Causality, Inferences- Test of Hypothesis and Diagnostic/Reliability Tests considerations. These sets of tests are designed to validate the goodness of the data sets for Unit Root to be stationary at their particular orders. The traditional (Dickey \& Fuller, 1976) test is adopted to show the unit root properties of the series following equation specified. 


$$
\Delta \mathrm{y}_{\mathrm{t}}=\beta_{1}+\beta_{2} \mathrm{t}+\delta \mathrm{y}_{\mathrm{t}-1}+\alpha_{\mathrm{i}} \sum_{t=1}^{m} \Delta \mathrm{y}_{\mathrm{t}-1}+\varepsilon_{\mathrm{t}}
$$

This is teat for stationary. Both the dependent variable ( $\mathrm{PCI})$, and independent variables of $(\mathrm{GCX}),(\mathrm{GRX})$ are subjected for test to avoid spurious data information Where the test is for $H_{o}=\delta=0$ and $H_{1}=\delta<0$.

\subsection{Granger Causality Representation}

After establishing a possible causal relationship through the granger causality model will be used to test the level of support emanating from the fiscal policies. This will follow the form specified below:

For the Model PCI as the dependent variable:

$$
\Delta \mathrm{PCI}_{t}=\pi_{p}+\sum_{i=1}^{k} \delta_{i p} \Delta \mathrm{PCI}_{t-i}+\sum_{i=1}^{k 1} \tau_{i p} \Delta G R X_{t-i}+\sum_{i=1}^{k 2} \theta_{i p} \Delta G C X_{t-i}+\varpi_{1 p} G R X_{t-1}+\varpi_{2 p} G C X_{t-1}+\xi_{1 t}
$$

The model above implies that the period's value of X being GRX and GCX has an explanatory influence on the current value Y being PCI.

All the variables are discussed above with combined modeling of the casual coefficients in the granger causality framework.

The prior expectations from the model's tests of the hypotheses are given as follows:

\subsection{Hypothesis One}

Ho: There are no significant causal relationships between the per capita income and fiscal policies of government recurrent expenditure and government capital expenditure in Nigeria.

Controlling for government recurrent expenditure and government capital expenditure as the explanatory variables of interest, the model for the hypothesis is presented thus:

$$
P C I_{t}=\gamma_{0}+\gamma_{1} G R X_{t}+\gamma_{2} G C X_{t}+\varepsilon_{t}
$$

Therefore the prior expectation with regards to this will be greater than zero; i.e. $\gamma_{1}, \gamma_{2},>0$

This equation denotes that the independent variables employ are expected to be greater than 0 , i.e. positive sign, since budget provision is an incremental to achieve the desired improve of per capita income in Nigeria.

\section{Results Presentation and Discussions of Findings}

Table-1. Data for per capita income (PCI), Government recurrent expenditures (GRX), government capital expenditures (GCX) in the Nigerian economy for the period 1981-2016. This table is periodic information of per capita income,

\begin{tabular}{|c|c|c|c|}
\hline Year & PCI & GRX & $\overline{G C X}$ \\
\hline 1981 & 685.35 & 4.85 & 6.57 \\
\hline 1982 & 692.62 & 5.51 & 6.42 \\
\hline 1983 & 729.44 & 4.75 & 4.89 \\
\hline 1984 & 789.3 & 5.83 & 4.1 \\
\hline 1985 & 879.55 & 7.58 & 5.46 \\
\hline 1986 & 872.87 & 7.7 & 8.53 \\
\hline 1987 & 1270.27 & 15.65 & 6.37 \\
\hline 1988 & 1635.61 & 19.41 & 8.34 \\
\hline 1989 & 2460.59 & 25.99 & 15.03 \\
\hline 1990 & 2955.29 & 36.22 & 24.05 \\
\hline 1991 & 3367.27 & 38.24 & 28.34 \\
\hline 1992 & 5542.18 & 53.03 & 39.76 \\
\hline 1993 & 6960.2 & 136.73 & 54.5 \\
\hline 1994 & 8974.9 & 89.97 & 70.92 \\
\hline 1995 & 18595.84 & 127.63 & 121.14 \\
\hline 1996 & 25277.37 & 124.49 & 212.93 \\
\hline 1997 & 25603.91 & 158.56 & 269.65 \\
\hline 1998 & 24198.89 & 178.1 & 309.02 \\
\hline 1999 & 27757.66 & 449.66 & 498.03 \\
\hline 2000 & 38555.41 & 461.6 & 239.45 \\
\hline 2001 & 39131.13 & 579.3 & 438.7 \\
\hline 2002 & 55400.52 & 696.8 & 321.38 \\
\hline 2003 & 66245.95 & 984.3 & 241.69 \\
\hline 2004 & 86219.74 & 1110.64 & 351.25 \\
\hline 2005 & 106055.7 & 1321.23 & 519.47 \\
\hline 2006 & 131191.7 & 1390.1 & 552.39 \\
\hline 2007 & 143022.4 & 1589.27 & 759.28 \\
\hline 2008 & 164055 & 2117.36 & 960.89 \\
\hline 2009 & 163443.7 & 2127.97 & 1152.8 \\
\hline 2010 & 349791.7 & 3109.44 & 883.87 \\
\hline 2011 & 391174.5 & 3314.51 & 918.55 \\
\hline 2012 & 433955.8 & 3325.16 & 874.7 \\
\hline 2013 & 471456.1 & 3214.95 & 1108.39 \\
\hline 2014 & 510805.4 & 3426.94 & 783.12 \\
\hline 2015 & 525316.4 & 3831.98 & 818.35 \\
\hline 2016 & 551511.4 & 4178.59 & 634.79 \\
\hline
\end{tabular}
government capital, and recurrent expenditures rates in Nigeria from 1981 to 2017. 
4.1. Data Analysis

4.1.1. ADF Unit Root Test Results

The Results of the Unit Root Test as Presented in Table 2.

Table-2. ADF - unit root test (Summary)

\begin{tabular}{|c|c|c|c|c|c|c|}
\hline \multirow{2}{*}{$\begin{array}{c}\text { Differenced } \\
\text { Variables }\end{array}$} & \multirow{2}{*}{$\begin{array}{c}\text { ADF - Test } \\
\text { Statistic }\end{array}$} & \multicolumn{3}{|c|}{ Test of Critical Level } & \multirow{2}{*}{$\begin{array}{c}\text { Order of } \\
\text { Integration }\end{array}$} & \multirow{2}{*}{$\begin{array}{c}\text { Probability } \\
\text { Value }\end{array}$} \\
\hline & & $1 \%$ & $5 \%$ & $10 \%$ & & \\
\hline $\mathrm{D}(\mathrm{PCI})$ & -4.779108 & -3.639407 & -2.951125 & -2.614300 & $1(1)$ & 0.0005 \\
\hline $\mathrm{D}(\mathrm{GRX})$ & -4.8124255 & -3.639407 & -2.951125 & -2.614300 & $1(1)$ & 0.0004 \\
\hline $\mathrm{D}(\mathrm{GCX})$ & -7.487938 & -3.639407 & -2.951125 & -2.614300 & $1(1)$ & 0.0000 \\
\hline
\end{tabular}

4.2. Test of Hypotheses

4.2.1. Test of Hypothesis One

Ho: There is no significant unit root between per capita income and each of the government recurrent expenditure, government capital expenditure in Nigeria.

$H a_{1}$ : There is a significant unit root between per capita income and each of the government recurrent expenditure, government capital expenditure in Nigeria.

In the table above the ADF test statistic of PCI (-4.779108), GRX (-4.8124255), and GCX( -7.487938$)$ are greater than the test critical level $-2.951125,-2.951125,-2.951125$ at 0.05 test critical level respectively. Also, the probability values of $0.0005,0.0004$ and 0.0000 are all less than 0.05 significance levels. Hence, the null hypothesis that the variables have a unit root and non-stationary is rejected at the 0.05 level of significance. This is for the fact that the Augmented Dickey-Fuller test statistics are greater than its critical, and its probability value is less the 0.05 level of significance as stated above. Thus, we can say that there exists no unit root among the variables in their first difference.

4.3. Granger Causality Test Results

The results of the Granger Causality Test as Presented in Table 3.

\begin{tabular}{|c|c|c|c|}
\hline \multicolumn{4}{|l|}{ Lags: 1} \\
\hline Null Hypothesis: & Obs & F-Statistic & Prob. \\
\hline GCX does not Granger Cause PCI & 35 & 20.6876 & 7.E-05 \\
\hline PCI does not Granger Cause GCX & & 0.04106 & 0.8407 \\
\hline GRX does not Granger Cause PCI & 35 & 14.0626 & 0.0007 \\
\hline PCI does not Granger Cause GRX & & 4.01362 & 0.0537 \\
\hline GRX does not Granger Cause GCX & 35 & 0.24016 & 0.6274 \\
\hline GCX does not Granger Cause GRX & & 10.4680 & 0.0028 \\
\hline
\end{tabular}

Ho: Fiscal policies did not significantly granger cause per capita income development in the Nigerian economy.

$\mathrm{Ha}_{2}$ : Fiscal policies significantly granger cause per capita income development in the Nigerian economy.

From the above results in Table 3 , the probability values indicate no significant Causal relationship between fiscal policies and per capita income. The null hypothesis is accepted concerning them, while the alternate is therefore rejected. Hence government recurrent expenditure is shown to be responding and adjusting to trends in Per capita income while capital expenditure operates independently. Conversely, these findings could be a result of poor management of the Nigerian budget. Also, it could be an indication of overpopulation and unemployment causing high dependency indices resulting in the dropping of per capita income. More so, poor data management could be a factor.

\section{Conclusion}

From the findings, it can be concluded that government recurrent expenditures constitute the significant policy variables of interest to promote and manage the desired growth rate of per capita income in the Nigerian economy. And government capital expenditures only cause changes to government recurrent expenditures which constitute derived effect. Some factors that were considered to be responsible for these findings were lack of political will in the distribution of budgetary provisions. Secondly, the upward growth of population and unemployment were also identifying as possible factors. Finally, poor data management was also traced as a possible indicator.

\section{Recommendations}

In light of the above findings, the study, therefore, suggested the below recommendation:

1. Nigerian Federal ministry should create employment opportunities or provide credits for businesses to reduce the rate of the unemployment rate.

2. Recurrent expenditures like transfer payments, salaries and wages should be promptly are paid to also help invigorate small businesses to improve the standard living of Nigerians citizens.

3. Those in public trust should in bide the political wellness to collate the right information and upon according without fear or favor. 


\section{References}

Abata, M. A., Kehinde, J. S., \& Bolarinwa, S. A. (2012). Fiscal/monetary policy and economic growth in Nigeria: A theoretical exploration. International Journal of Academic Research in Economics and Management Sciences, 1(5), 75-88.

Anyalechi, K. C., Onwumere, J. U. J., \& Boloupremo, T. (2017). Fiscal policy and the Nigeria economy: An econometric review. International Journal of Business and Management, 12(4), 186-196.

Devarajan, S., Swaroop, V., \& Zou, H. (1996). The composition of public expenditure and economic growth. Journal of Monetary Economics, 37(2-3), 313-344.

Dickey, D. A., \& Fuller, W. A. (1976). Distribution of Estimators for time series regression with a unit root. Journal of American Statistical Association, 74(366), 427-431.

Hertog, J. D. (1999). 500o general theories of regulation: Economic Institute/CLAV: Utrecht University.

Michael, A. A., \& Olufemi, A. A. (2017). Evaluating the relative impact of monetary and fiscal policy in Nigeria using the St. Louis Equation. Acta Universitatis Danubius. OEconomica, 13 (1), 40-50.

Monogbe, T. G., Achugbu, A., \& Davies, N. L. (2016). Fiscal policy, co-integration and economic stability in Nigeria (Preliminary Investigation). International Journal of Advanced Academic Research/Social \&ं Management Sciences, 2(10), 1-16.

Morakinyo, F. O., David, J. O., \& Alao, J. A. (2018). Impact of fiscal policy instrument on economic growth in Nigeria. International Journal of Economics and Financial Management, 3(1), 14-29.

Neter, J., Wasseraman, N., \& Kutner, M. H. (1989). Applied linear regression models (4th ed.). USA: Richard D. Iwin Inc.

Ogbole, O. F., Amadi, S. N., \& Essi, I. D. (2011). Fiscal policy: Its impact on economic growth in Nigeria 1970 to 2006. Journal of Economics and International Finance, 3(6), 407-417.

Seymour, D., \& Oral, W. (1997). Impact of government expenditures and economic Growth in the OECS: A disaggregated approach.

Snowdon, B., Vane, H. R., \& Wynarczyk, P. (1994). A modern guide to macroeconomics: An introduction to competing schools of thought, Alder-shot. UK and Brookfield, US: Edward Elgar.

Steven, A. (2017). Highlights of 2018 FGN budget of consolidation presentation speech. Asset Management Research. Retrieved from: www.infocusinternational.com.

Tsoukis, C., \& Miller, N. J. (2003). Public services and endogenous growth. Journal of Policy Modeling, 25(3), $297-307$.

Victor, O. U. (2017). Monetary and fiscal policy coordination in Nigeria: A set theoretic approach. Academic Journal of Economic Studies, 3(1), 48-58. 